\title{
Macroeconomic Implications of Capital Inflows in India
}

\author{
Dr. Md. Izhar Ahmad ${ }^{1}$, Tariq Masood $^{2}$
}

\begin{abstract}
:
The study attemts to analyse the behaviour of some macroeconomic variables in response to Total Capital Inflows in India using quarterly data for the period 1994-2007.

The paper consist two sections, in first section we have analysed trend behaviour of macroeconomic variables included in the study. Time trend of all variables except NEERX, NEERT and CAB shows instability over the period of study.

In second section we have have made an attempt to impirically analyse the behaviour of some macroeconomic variables. With the help of DF, ADF and Schmidt \& Phillips test we have concluded that $C A B$ is the only variable which stationary in level form all othe variables are stationary in first difference form.

Cointegration test confirms the long run equilibrium relation between REERX \& TCI, REET \&TCI and between NEERX \& TCI. Granger causality test confirms the bidirectional causality between REERX \& TCI and between FOREX \& TCI and unidirectional causality from TCI to REERT.
\end{abstract}

Key Words: Capital inflows, cointegration analysis.

\footnotetext{
${ }^{1}$ Reader Dept. of Economics AMU, Aligarh. India, izharshaista@gmail.com

${ }^{2}$ Research Scholor Dept.of Economics AMU, Aligarh, India, tariqmasood8@gmail.com
} 


\section{Introduction}

Since 1991 India has undertaken various reform measures to liberalize the economy. These measures include removal of industrial licensing system, reduction in trade barriers, and liberalization of capital flows. Over the last several years restrictions on various components on capital account have been relaxed. Due to the various policy measures undertaken by Indian Govt. to liberalize capital flows not only amount of capital inflows increases tremendously but also the composition of capital flows changed significantly. Net capital flows as percentage of GDP increases from $2.2 \%$ in 1990-91 to around $9 \%$ in 2007-08.

The composition of capital flows has undergone a complete change from official debt flows to non debt flows. The share of private capital flows viz. FDI, FII increases while the share of official flows decreases. Fig.1. shows the time series plot of total capital inflows and its components using yearly data for the period 1994-2006. Trend behavior of foreign direct investment does not show much fluctuation while all other component shows variability over the period.

Fig.1 Total Capital Inflows \& its Components

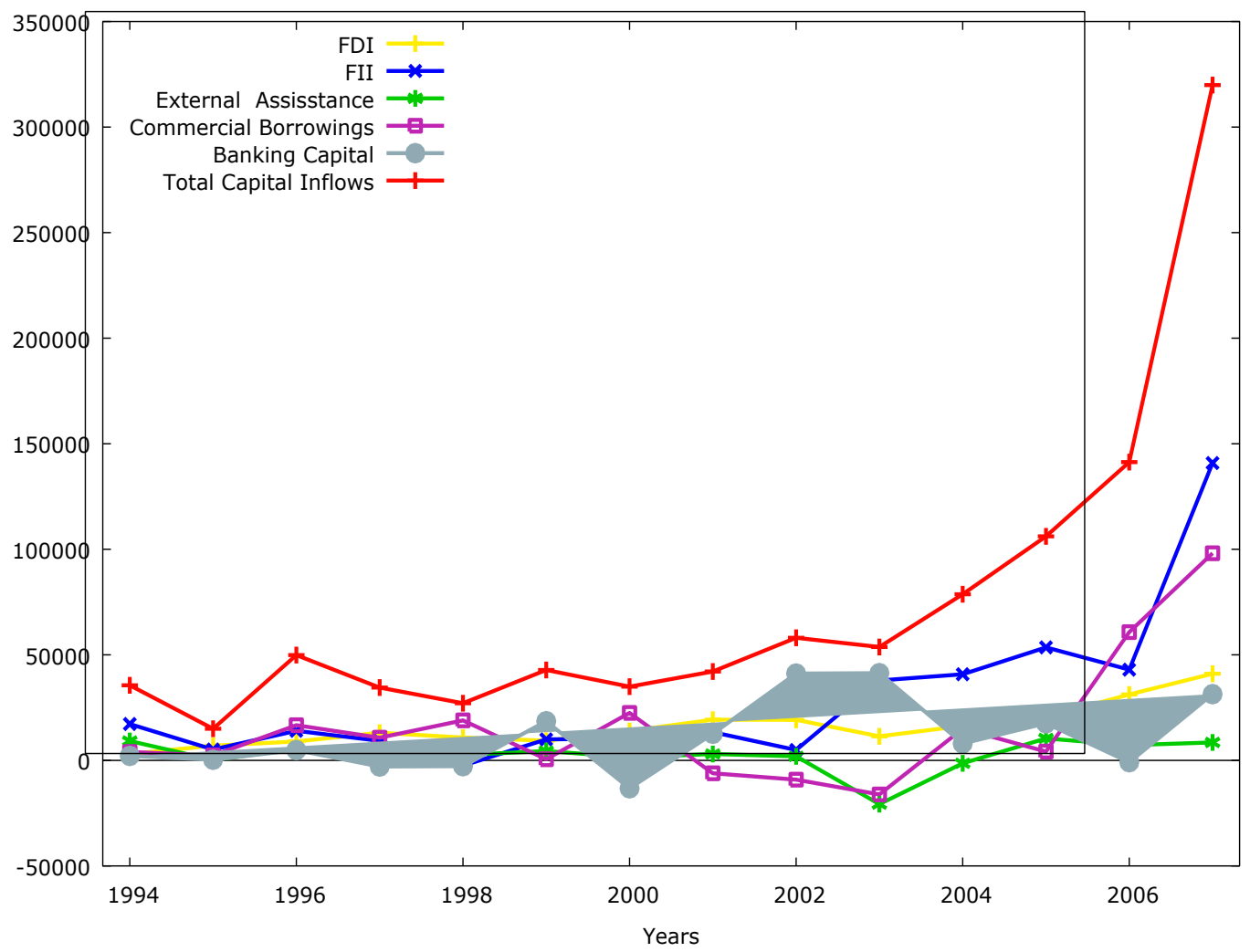


Various Latin American and Asian countries have opened their capital account in the past. Different countries have experienced different consequences in response to large capital inflows. Due to large capital inflows and flexible exchange rate various Latin American countries have experienced large appreciation of domestic currency and consequent deficit in the current account. Other possible effects of capital inflows are monetary expansion in the economy and consequent rise in inflation, rise in bank lending and effects upon savings and investment.

Calvo, Leiderman and Reinhart (1996) while analyzing the impact of capital inflows on a number of Asian and Latin American countries concluded that several Asian countries have experienced capital inflows similar to those in Latin America without associated sizable appreciation of the real exchange rate.

Cohli (2001) examined the trend of capital inflows in India and impact of these flows on some key macroeconomic variables. The study shows that the real exchange rate appreciates in response to capital inflows. The paper also highlights the pressure of capital inflows upon domestic money supply.

Chakraborty (2001) examined the effects of private foreign capital on some major macroeconomic variables in India using quarterly data for the period 1993-99. The analyses of trends in private foreign capital inflows and some other variables indicate instability. Net inflows of private foreign capital, foreign currency assets, wholesale price index, money supply, real and nominal effective exchange rate and exports follows an I(1) process, current account balance is the only variable that follows $\mathrm{I}(0)$ process. Cointegration test shows the presence of long run relationship between a few pair of variables. The Granger causality test shows the unidirectional from private foreign capital to nominal effective exchange rates- both trade based and export based.

Indrani Chakraborty (2003) using VAR model for the period 1993Q2 to 2001Q4 concluded that unlike East Asian and Latin American countries, the real exchange rate depreciates with respect to one standard deviation innovation to capital inflows. The paper argues that monetary policy was effective in avoiding any serious distortion in the real exchange rate.

Pami Dua and Partha Sen (2006) while analyzing the relationship between the real exchange rate, level of capital flow, volatility of the flows, fiscal and monetary policy indicators and current account surplus for the period 1993Q2 to 2004Q1 concluded that variables are cointegrated and each Granger causes the real exchange rate. The generalized variance decomposition shows that determinants of the real exchange rate in descending order of importance include net capital inflows and volatility (jointly), government expenditure, current account surplus and the money supply.

Theories exploring the consequenses of capital inflow are too complex and it is extremely difficult to formulate econometric model that reflect these complexities (Thalassinos et al, 2012a; 2012b; 2013; Hanias et al, 2007). The paper is not an 
attempt to formulate econometric model of simultaneous determination of above variables but analyses the impact of capital inflows on individual variables. The paper consist of two sections, the first section analyses trend behaviour of some macroeconomic variables in response to capital inflow with the help of time series plot and second section with the help of econometric tecqniques empirically analyses impact of capital inflow on some of the macroeconomic variables in india.

\section{Data Source and Variables Included}

The Study attempts to analyse the impact of capital inflow on some macroeconomic variables in India using quarterly data for the period 1994Q1 to 2007Q2.Macroeconomic Variables included in the study are Total Capital Inflows (TCI), Real \& Nominal Effective Exchange Rate (both export based \&trade based), Whole sale Price index (WPI), Money Supply (M0), Foreign Exchange Reserve (FOREX) and Current Account Balance (CAB).

Two measures of real effective and nominal effective exchange rate based on export base and trade base using 36 countries weight have been taken. Total capital inflows (TCI) is the aggregate of foreign direct investment (FDI), foreign institutional investment (FII), external assistance (EA), banking capital (BC) and commercial borrowing (CB). All the variables are compiled from various publication of viz. Handbook of Statistics on Indian Economy and RBI Bulletin.

\section{Trend Behaviour of Some Macroeconomic Variables in Response to Total Capital Inflows}

Under flexible exchange rate with no intervention by the central bank capital inflows generate no change in reserves and cause exchange rate to appreciate. Exchange rate policy in India is managed floating rather than pure floating. Central bank plays active role in minimising volatility in foreign exchange market. Fig.3 shows the behaviour of the real and nominal exchange rate over the period 1994Q1-2007Q4.

Time series plot of nominal exchange rate (both export based \& trade based) shows negative trend over the period of study. Time series plot of real effective exchange rate (both export \& trade based) shows some upward trend specially after the year 1999. Behaviour of NEER shows the active interventionist role played by the RBI to reduce the volatility in foreign exchange market. Gap between NEER \& REER increases over the time which is due to the price differential in domestic economy and World economy.

The pairwise correlation between TCI and NEER is very low and insignificant, but there is a positive significant correlation between TCI and REER. The year 2007 witnessed huge inflows of foreign capital mainly due to FIIs and also high appreciation of both real and nominal effective exchange rate. 
Fig.2.Total Capital Inflows vs. Exchange Rates

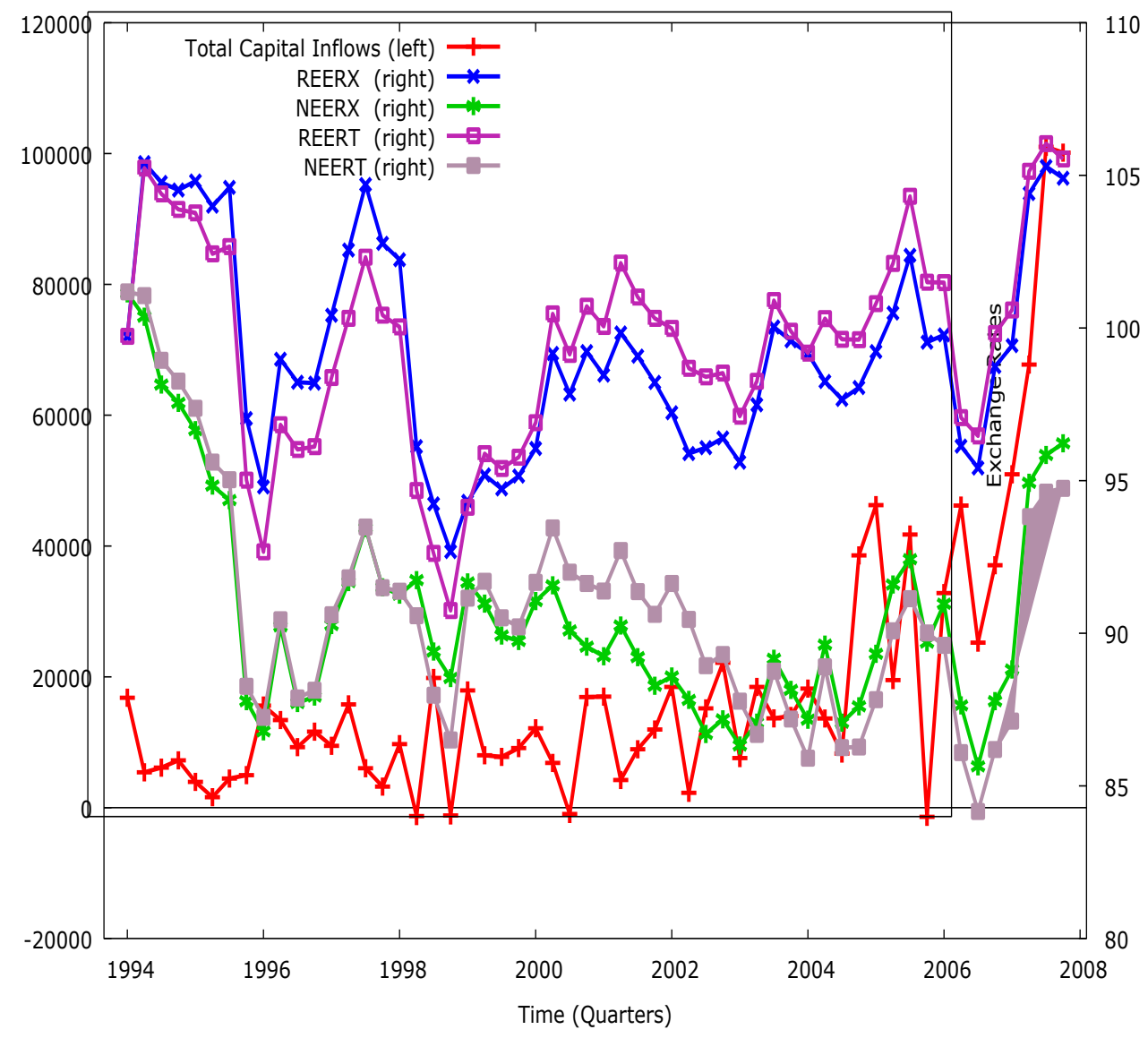

Intervention by the central bank in foreign exchange market results in changes in foreign exchange reserves so it will be fruitfull now to analyse the behaviour of foreign exchange reserves in response to total capital inflows. Fig. 3 shows foreign exchange reserves increases tremendously over the period. In level form there is a high correlation $(0.796)$ between total capital inflows and foreign exchange reserves (Table 1).

Table 1. Correlation Matrix

\begin{tabular}{|l|r|r|r|r|r|r|r|r|r|}
\hline & TCI & \multicolumn{1}{|l}{ REER } & NEER & REER2 & NEERT & WPI & M0 & FOREX & CAB \\
\hline TCI & 1 & $.271^{*}$ & .138 & $.380^{* *}$ & -.041 & $.669^{* *}$ & $.810^{* *}$ & $.796^{* *}$ & -.254 \\
\hline $\begin{array}{l}\text { REE } \\
\text { RX }\end{array}$ & $.271^{*}$ & 1 & $.725^{* *}$ & $.887^{* *}$ & $.665^{* *}$ & -.074 & .076 & .115 & -.164 \\
\hline $\begin{array}{l}\text { NEE } \\
\text { RX }\end{array}$ & .138 & $.725^{* *}$ & 1 & $.599^{* *}$ & $.933^{* *}$ & $-.370^{* *}$ & -.171 & -.146 & -.187 \\
\hline
\end{tabular}




\begin{tabular}{|l|l|r|r|r|r|r|r|r|r|}
\hline $\begin{array}{l}\text { REE } \\
\text { RT }\end{array}$ & $.380^{* *}$ & $.887^{* *}$ & $.599^{* *}$ & 1 & $.586^{* *}$ & .238 & $.332^{*}$ & $.359^{* *}$ & -.103 \\
\hline $\begin{array}{l}\text { NEE } \\
\text { RT }\end{array}$ & -.041 & $.665^{* *}$ & $.933^{* *}$ & $.586^{* *}$ & 1 & $-.497^{* *}$ & $-.338^{*}$ & $-.336^{*}$ & -.093 \\
\hline WPI & $.669^{* *}$ & -.074 & $-.370^{* *}$ & .238 & $-.497^{* *}$ & 1 & $.960^{* *}$ & $.945^{* *}$ & -.137 \\
\hline MO & $.810^{* *}$ & .076 & -.171 & $.332^{*}$ & $-.338^{*}$ & $.960^{* *}$ & 1 & $.988^{* *}$ & -.221 \\
\hline FORE & $.796^{* *}$ & .115 & -.146 & $.359^{* *}$ & $-.336^{*}$ & $.945^{* *}$ & $.988^{* *}$ & 1 & -.218 \\
\hline X & & & & & & & & & \\
\hline CAB & -.254 & -.164 & -.187 & -.103 & -.093 & -.137 & -.221 & -.218 & 1 \\
\hline
\end{tabular}

Due to the trending behaviour of the foreign exchange reserves it is difficult to analyse its behaviour in response to total capital inflows. Fig.3 also shows the behaviour of reserves in first difference form which is simply quarterly change in reserves. Quarterly change in reserves is the variable which is more closely related to the total capital inflows. Periods of high capital inflows are associated with large increase in reserves and periods of low capital inflows are associated with the relatively lower increse or decrease in reserves. Close association between capital inflows and foreign exchange reserves also suggest the active role played by the central bank in foreign exchange market.

Fig.3. Total Capital Inflows vs. FOREX

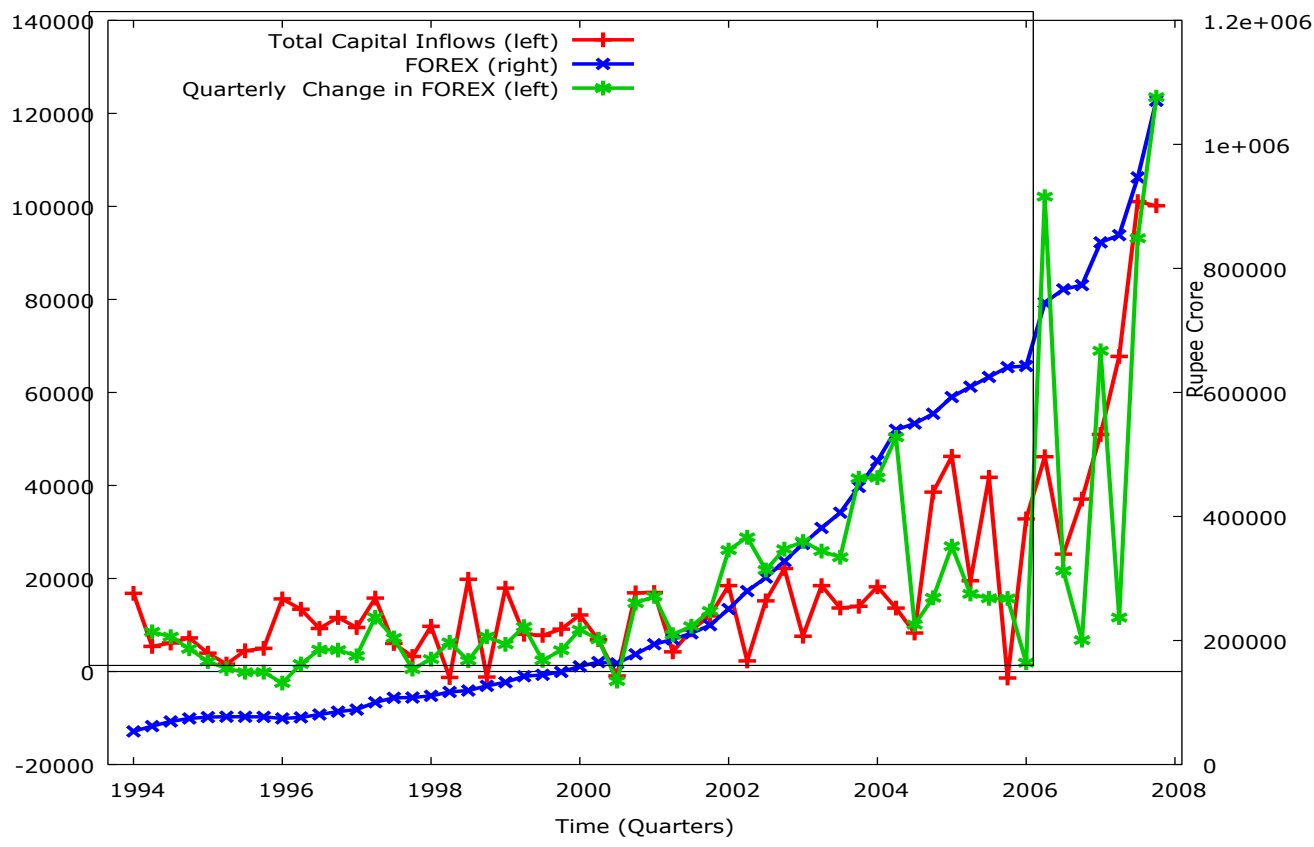


There are two types of intervention by the central bank in foreign exchange market. In first type, Central bank purchases foreign exchange against domestic currency to prevents appreciation of currency. Foreign exchange reserve being one component of reserve money, such intervention leads to the growth of high-powered money and consequently increases the money supply in the economy. The second type of central bank intervention is known as "sterilized intervention".

In this process the central bank buys foreign exchange in exchange of government securities. It helps to curb the growth of money supply in the economy. Time series plot of money supply shows the explosive behavior. Money supply increases tremendously over the period of the study. To trace the behavior of the money supply in response to capital inflows we have also plotted quarterly change in money supply.

Fig.4. Total Capital Inflows Vs. M0

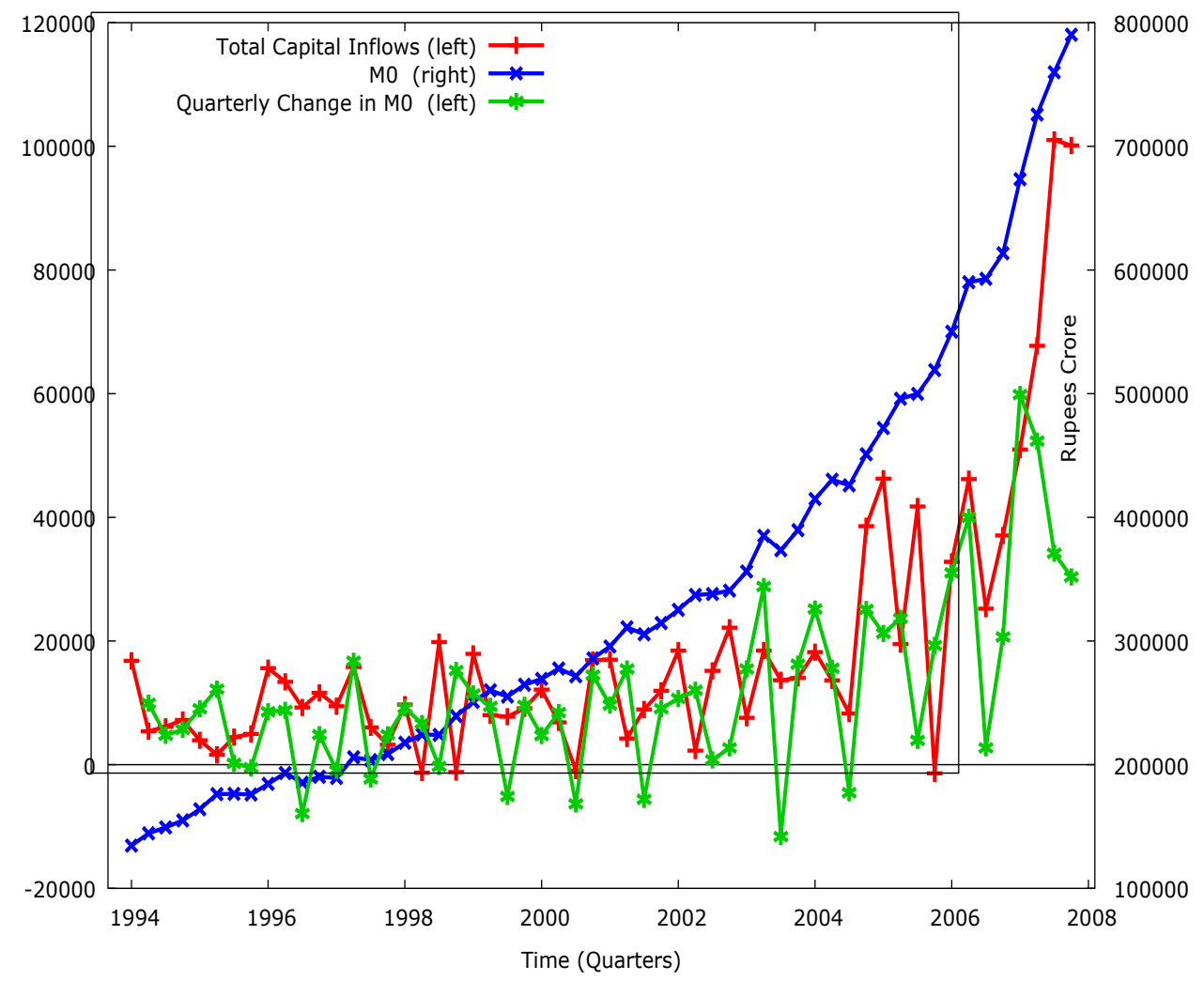

To analyse the behaviour of price level we plotted the quarterly inflation over the time period of 1995Q1 to 2007Q4. The behaviour of the variable under consideration does not show much divergence though there are some episodes of high inflation. Simple time series plot of inflation and capital inflows does not suggest much about the underlying relationship between two variables. 
Due to the price stabilization policies of the Government price remains under control during the period of the study. High capital inflows are not always associated with high inflation specialy during the year 2007 despite huge surge of capital inflows price level decelarates. The relationship between inflation and capital inflows is complex and one can not conclude much with simple time series plot.

At last we have analysed behaviour of current account balance (fig.6). In literature 'Dutch Desease Dilema' suggests the deterioration of current account in response to large capital inflows in the long run. Time series plot of current account balance does not show any trend over the period of the study.

Correlation coefficient (-0.25) between total capital inflows and current account balance shows some inverse relationship between the two variables (Table 2) but the value of correlation coefficient is not significant. Thus the notion of Ducth Desease Dilema has not been observed in the context of India.

Fig.5. Total Capital Inflows vs. Inflation

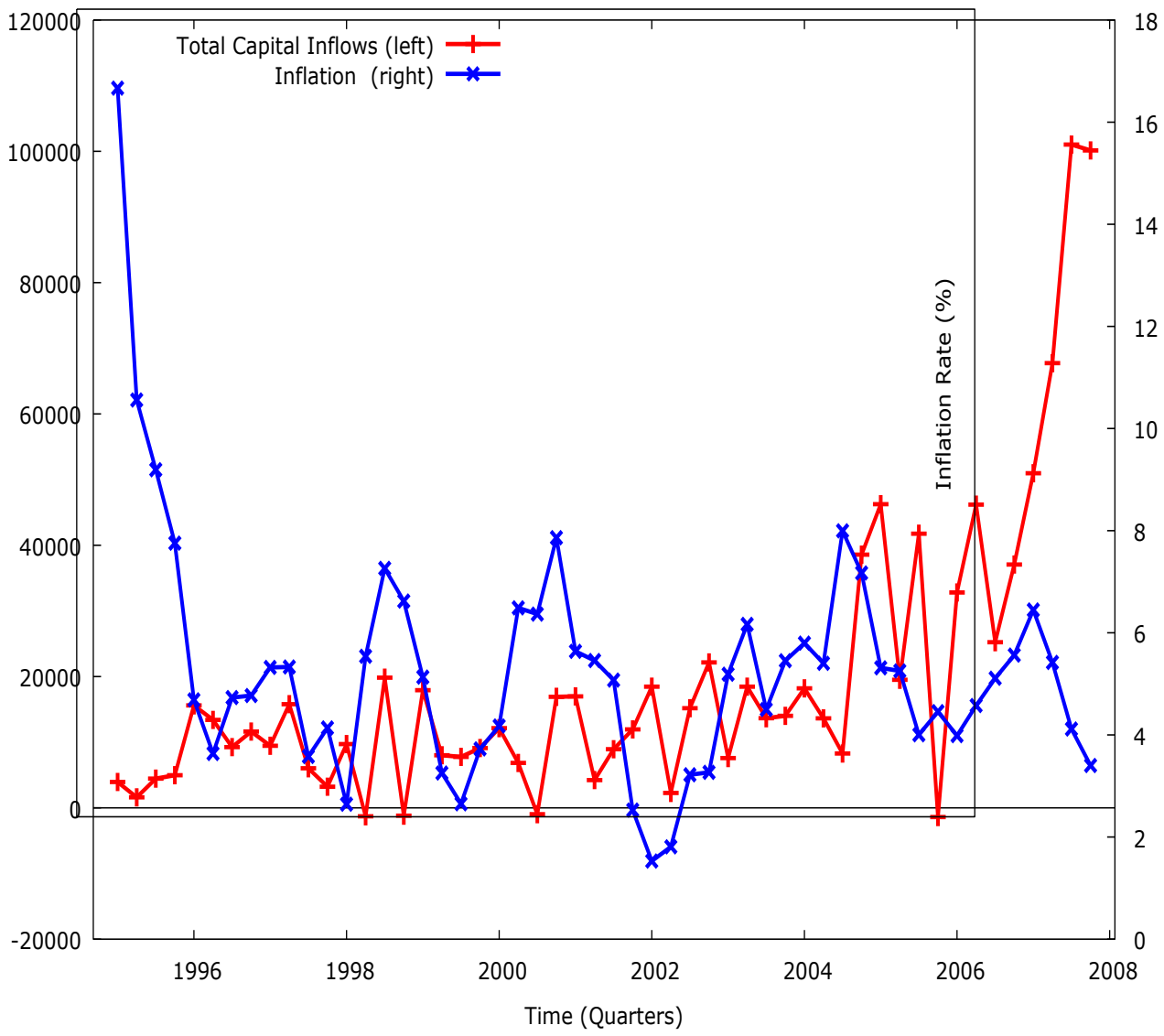


Table 2. Summary Statistics

\begin{tabular}{|c|c|c|c|c|c|c|}
\hline Variables & Range & Minimum & Maximum & Mean & Std. Dev. & Variance \\
\hline FDI & 18089 & -3374 & 14715 & 4017.34 & 3360.128 & $1.129 \mathrm{E} 7$ \\
\hline FII & 60161 & -2301 & 57860 & 7100.66 & 10990.970 & $1.208 \mathrm{E} 8$ \\
\hline EA & 17601 & -12138 & 5463 & 650.82 & 2754.345 & 7586417.93 \\
\hline CBs & 47578 & -18756 & 28822 & 3970.68 & 9131.27 & 8.338E7 \\
\hline BC & 40923 & -14004 & 26919 & 2824.50 & 7428.84 & 5.519E7 \\
\hline TCI & 102430 & -1400 & 101030 & $\begin{array}{r}18564.0 \\
0\end{array}$ & 21342.13 & $4.555 \mathrm{E} 8$ \\
\hline REERX & 12.74 & 92.67 & 105.41 & 99.19 & 3.37 & 11.391 \\
\hline NEERX & 15.49 & 85.64 & 101.13 & 90.64 & 3.54 & 12.568 \\
\hline REERT & 15.29 & 90.74 & 106.04 & 99.49 & 3.41 & 11.660 \\
\hline NEERT & 17.02 & 84.16 & 101.18 & 90.80 & 3.75 & 14.103 \\
\hline WPI & 116 & 100 & 216 & 158.17 & 31.55 & 995.942 \\
\hline M0 & $\begin{array}{r}655718.6 \\
6\end{array}$ & 134552.66 & 790271.33 & $\begin{array}{r}338472 . \\
25\end{array}$ & 168133.67 & $2.827 \mathrm{E} 10$ \\
\hline FOREX & 1016870 & 53412 & 1070282 & $\begin{array}{r}318374 . \\
67\end{array}$ & 274282.22 & $7.523 \mathrm{E} 10$ \\
\hline CAB & 13658 & -6301 & 7357 & -802.30 & 2922.90 & 8543378.21 \\
\hline
\end{tabular}


Fig.6.Total Capital Inflow vs. Current Account Balance

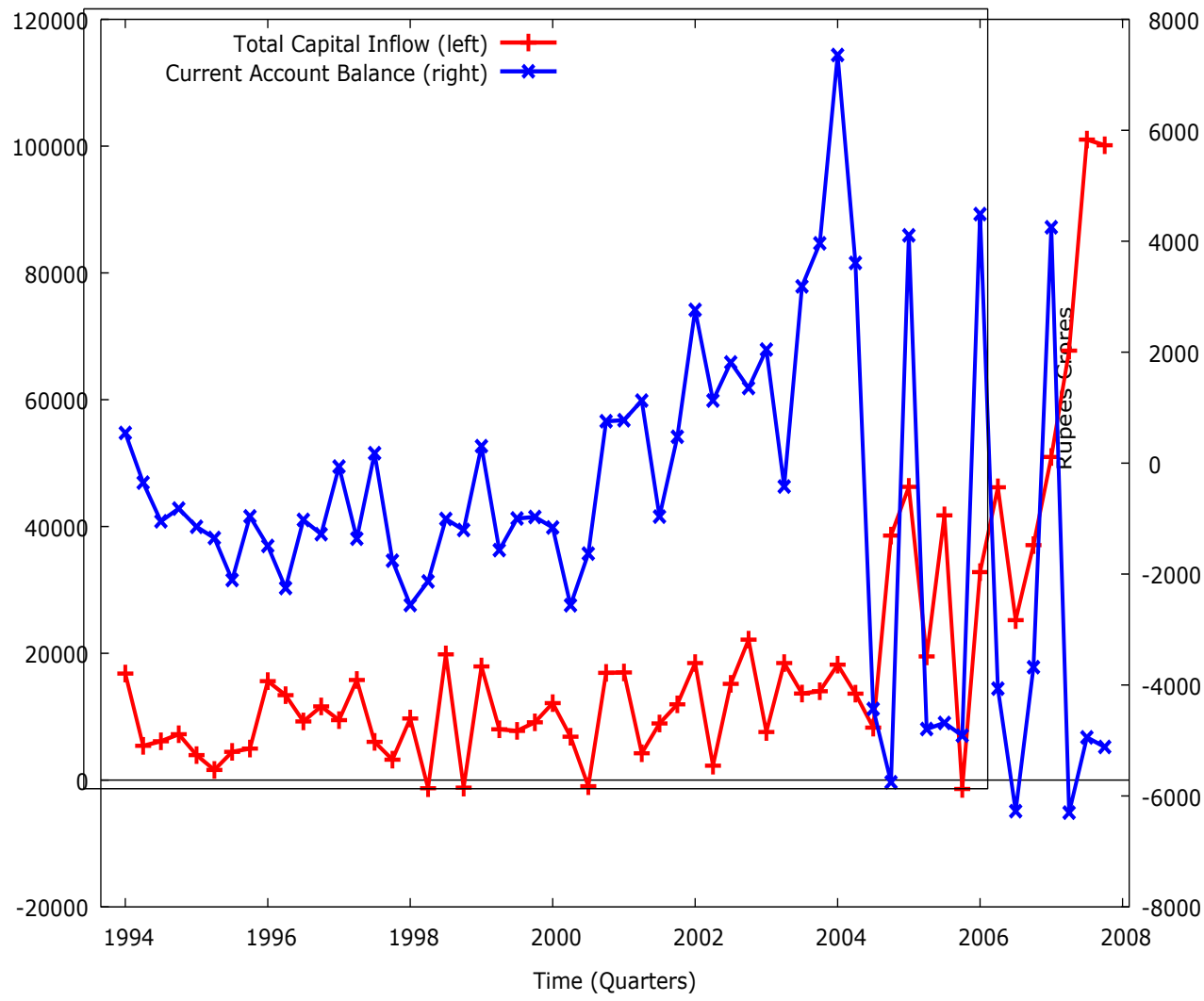

\section{Econometric Analysis and Findings}

In this section we have applied some econometric test to empirically analyze the behavior of some macroeconomic variables in response to total capital inflows. First, tests of stationarity are applied to each variable. Three tests of stationarity viz. DF test, ADF test and Schmidt and Phillips test have been applied. Since there is no universal test for unit root we will conclude with the help of three tests. DF test is based on the following regression:

$$
\Delta \mathrm{Y}_{\mathrm{t}}=\mathrm{C}+\alpha \mathrm{t}+\rho \mathrm{Y}_{\mathrm{t}-1}+\varepsilon_{\mathrm{t}}
$$

Where $\mathrm{C}$ is constant and $\mathrm{t}$ is trend.

Null Hypothesis $\mathrm{H}_{\mathrm{O}}: \rho=1 \quad$ or $\mathrm{Y}_{\mathrm{t}}$ is non stationary

$\mathrm{H}_{1}: \rho<1 \quad$ or $\mathrm{Y}_{\mathrm{t}}$ is stationary

The null hypothesis is rejected if $\rho$ is negative and statistically significant.

The ADF test is based on the following regression: 


$$
\Delta \mathrm{Y}_{\mathrm{t}}=\mathrm{C}+\alpha \mathrm{t}+\rho \mathrm{Y}_{\mathrm{t}-1}+\sum_{i=1}^{n} \beta_{\mathrm{i}} \Delta \mathrm{Y}_{\mathrm{i}-1}+\varepsilon_{\mathrm{t}}
$$

If $\mathrm{C}$ and $\alpha$ failed to be statistically significant we run above regression again dropping the constant and trend. For the choice of appropriate number of lags we have followed Enders (1995). We start with a large lag (n), if the estimated tstatistics for the last lag is not significant, we drop the last lag and repeat the process. The process will continue until we find a lag which is significant.

DF test confirms the presence of non stationarity in the level form for the variables TCI, REERX, REERT WPI, FOREX, and MO. NEERX and NEERT follows I(0) process at $5 \%$ level of significance. $\mathrm{CAB}$ is stationary at $1 \%$ level of significance. $\mathrm{ADF}$ test confirm the presence of non stationarity in the level form for variables TCI, REERX, WPI, FOREX and MO. NEEERX and NEERT are stationary in level form at $1 \%$ level of significance. REERT is stationary at $10 \%$ level of significance and $\mathrm{CAB}$ is stationary at $5 \%$ level of significance.

Schmidt and Phillips (1992) have proposed a test for the null hypothesis of a unit root when a deterministic linear trend is present. They suggest estimating the deterministic term in a first step under the unit root hypothesis. Then the series is adjusted for the deterministic terms and a unit test is applied to the adjusted series. Schmidt and Phillips test confirms that all variables except CAB are non stationary. In first difference form WPI is stationary at 5\% level of significance; all other variables (TCI, REERX, NEERX, NEERX, NEERT, FOREX and MO) are stationary at $1 \%$ level of significance.

With the help of the above three test we have concluded that TCI, REERX, REERT, WPI, FOREX, and MO are variables which follows I(1) process. DF and ADF test shows that NEERX and NEERT follows I(0) while Schmidt and Phillips test shows they follows $\mathrm{I}(1)$ process. All the three test confirms CAB follows $\mathrm{I}(0)$ process hence we leaves $\mathrm{CAB}$ for further analysis.

Non stationarity of a variable shows that the time path of the variable concerned is diverging from equilibrium. Hence time path of $\mathrm{CAB}$ does not diverge from equilibrium. There is also evidence that NEERX and NEERT follow I(0) and hence time path shows stability over time.

After tests of stationarity we have applied the test of Cointegration to explore the long run equilibrium relation between a set of variables. If two or more variables which are integrated of the same order are cointegrated then it follows that there exist long run equilibrium relation between them. To test the cointegrating relation between pair of variables we have followed the methodology suggested by Engle and Granger (1987). Engle Granger co integration test is based on two stage regression. In the first stage we have run the following regression

$$
Y_{t}=\beta_{0}+\beta_{1} t+\beta_{2} X_{t}+u_{t}
$$


If the coefficient of time trend $t$ comes out insignificant we have re run the above regression by dropping the time trend t. In second stage we have run following regression

$$
\Delta \hat{\mathrm{u}}_{\mathrm{t}}=\delta \hat{\mathrm{u}}_{\mathrm{t}-1}+\alpha_{\mathrm{i}} \sum \Delta \hat{\mathrm{u}}_{\mathrm{t}-1}+\varepsilon_{\mathrm{t}}
$$

The figures given in table (5) are $\mathrm{t}$ values of $\delta$. Co integration exist between following pair of variables: REERX and TCI, NEERX and TCI, REERT and TCI. No other variable is cointegrated with TCI. In addition cointegration exists between following pair of variables: REERT and WPI, REERT and MO, REERT and FOREX, NEERT and WPI, NEERT and FOREX and between Mo and FOREX.

In last we have applied the causality test to explore the unidirectional or bidirectional causality between pair of variables. If a variable $\mathrm{X}$ causes $\mathrm{Y}$ and also $\mathrm{Y}$ causes $\mathrm{X}$ then there is a feedback or bidirectional causality and if only one variable causes other then there is unidirectional causality. In literature number of tests for detecting causality have been discussed but we have used one of the oldest test of causality namely Granger test. The intuition behind the granger causality test is that if $X$ Granger causes Y but Y does not Granger cause X, then past values of X should be able to help predict future values of $Y$, but past values of $Y$ should not be helpful in predicting X. Since stationarity of variables is precondition for Granger causality test we have used first difference form of variables. The following model has been applied:

$$
\begin{aligned}
& \mathrm{Yt}=\sum_{i=1}^{p} \alpha_{\mathrm{i}} \mathrm{X}_{\mathrm{t}-\mathrm{i}}+\sum_{i=1}^{p} \beta_{\mathrm{j}} \mathrm{Y}_{\mathrm{t}-\mathrm{j}}+\mathrm{u}_{1 \mathrm{t}} \\
& \mathrm{X}_{\mathrm{t}}=\sum_{i=1}^{p} \gamma_{\mathrm{i}} \mathrm{X}_{\mathrm{t}-\mathrm{i}}+\sum_{i=1}^{p} \delta_{\mathrm{j}} \mathrm{Y}_{\mathrm{t}-\mathrm{j}}+\mathrm{u}_{2 \mathrm{t}}
\end{aligned}
$$

$\mathrm{P}$ is the order of the lag. Lag selection is a difficult choice for which we have used Akaike criterion. The null hypothesis that X does not granger causes $Y$ is that $\alpha_{i}=0$ for $\mathrm{i}=1,2, \ldots . . \mathrm{p}$. the figures reported in table. 6 are Wald $\mathrm{F}$ statistics and corresponding $\mathrm{p}$ values.

The first significant result which we get is get is bidirectional causality exist between TCI \& REERX and unidirectional causality from TCI to REERT. There is no causality between TCI \& NEERX or between TCI \& NEERT. Again bidirectional causality exist between TCI \& FOREX. In addition unidirectional causality from REERT to FOREX, MO to NEERT, WPI to FOREX and bidirectional causality between MO \& WPI exists (Tables 3-5). 
Table 3. DF \& ADF Test

\begin{tabular}{|c|c|c|c|c|}
\hline & DF Test & & ADF Test & \\
\hline Variables & Level & First Difference & Level & $\begin{array}{l}\text { First } \\
\text { Difference }\end{array}$ \\
\hline TCI & $\begin{array}{l}-2.5949 \\
\text { With C \& T }\end{array}$ & $\begin{array}{l}-11.3428 * * * \\
\text { With C }\end{array}$ & $\begin{array}{l}4.793 \\
\text { With C, Lag- } \\
10\end{array}$ & $\begin{array}{l}-4.1755^{* * *} \\
\text { With C, Lag-11 }\end{array}$ \\
\hline REERX & $\begin{array}{l}-2.307 \\
\text { With C }\end{array}$ & $\begin{array}{l}-7.01939 * * * \\
\text { With C }\end{array}$ & $\begin{array}{l}-1.6872 \\
\text { With C, Lag- } \\
15\end{array}$ & $\begin{array}{l}-5.2671 * * * \\
\text { With C, Lag-5 }\end{array}$ \\
\hline NEERX & $\begin{array}{l}-3.0908^{* *} \\
\text { With C }\end{array}$ & $\begin{array}{l}-7.4581^{* * * *} \\
\text { With C }\end{array}$ & $\begin{array}{l}-3.9235^{* * *} \\
\text { With C, Lag-6 }\end{array}$ & $\begin{array}{l}-4.5001 * * * \\
\text { With C, Lag-5 }\end{array}$ \\
\hline REERT & $\begin{array}{l}-2.31964 \\
\text { With C }\end{array}$ & $\begin{array}{l}-7.08713 * * * \\
\text { With C }\end{array}$ & $\begin{array}{l}-3.305^{*} \\
\text { With C\&T, } \\
\text { Lag-1 }\end{array}$ & $\begin{array}{l}-4.9903 * * * \\
\text { With C, Lag-5 }\end{array}$ \\
\hline NEERT & $\begin{array}{l}-3.09247^{* *} \\
\text { With C }\end{array}$ & $\begin{array}{l}-6.79982 * * * \\
\text { With C }\end{array}$ & $\begin{array}{l}-3.9067 * * * \\
\text { With C, Lag-6 }\end{array}$ & $\begin{array}{l}-4.1277 * * * \\
\text { With C, Lag-5 }\end{array}$ \\
\hline WPI & $\begin{array}{l}-2.22089 \\
\text { With C \& T }\end{array}$ & $\begin{array}{l}-7.99156^{* * * *} \\
\text { With C }\end{array}$ & $\begin{array}{l}-1.707 \\
\text { With C\&T, } \\
\text { Lag-4 }\end{array}$ & $\begin{array}{l}-4.0573 * * * \\
\text { With C\&T Lag- } \\
3\end{array}$ \\
\hline FOREX & $\begin{array}{l}6.4428 \\
\text { With C }\end{array}$ & $\begin{array}{l}-5.5367 * * * \\
\text { With C \& T }\end{array}$ & $\begin{array}{l}3.0328 \\
\text { With C, Lag- } \\
11\end{array}$ & $\begin{array}{l}-3.1655^{* * *} \\
\text { With C\&T Lag- } \\
8\end{array}$ \\
\hline M0 & $\begin{array}{l}6.1548 \\
\text { With C }\end{array}$ & $\begin{array}{l}-6.37034^{* * * *} \\
\text { With C \& T }\end{array}$ & $\begin{array}{l}3.2604 \\
\text { With C\&T, } \\
\text { Lag-11 }\end{array}$ & $\begin{array}{l}-3.6879 * * * \\
\text { With C, Lag-4 }\end{array}$ \\
\hline CAB & $\begin{array}{l}-5.46898 * * * \\
\text { With C }\end{array}$ & & $\begin{array}{l}-3.149 * * \\
\text { With C, } \\
\text { Lag-13 }\end{array}$ & $\begin{array}{l}-4.1440 * * * \\
\text { With C, Lag-3 }\end{array}$ \\
\hline
\end{tabular}

Notes:

(i) Critical Values at 1\%, 5\% \& 10\% With C\& $T$ are $-3.96,-3.14,-3.13$ resp., with $C$ without $T$ are $-3.43,-2.86,-2.57$ resp. and without $C \& T$ are -2.56, -

1.94, -1.62 resp. Davidson, $R$. and MacKinnon, J. (1993), "Estimation and Inference in Econometrics" p 708, table 20.1,Oxford University Press, London

(ii) ' $C$ ' stands for constant and ' $T$ ' stands for trend

(iii) $* * *$ signifies statistically significant at $1 \%$ level

(iv) ** signifies statistically significant at $5 \%$ level

(v) * signifies statistically significant at $10 \%$ level 
Table 4. Schmidt-Phillips Test

\begin{tabular}{|lll|}
\hline Variable & Level Form & First Difference \\
\hline REERX & -2.5711 & $-11.1641^{* * *}$ \\
\hline NEERX & -2.4810 & $-4.2808 * * *$ \\
\hline REERT & -2.4803 & $-6.0020^{* * *}$ \\
\hline NEERT & -2.5923 & $-4.2808^{* * *}$ \\
\hline WPI & -2.6472 & $-5.7530 * * *$ \\
\hline FOREX & -1.8108 & $-3.2599 * *$ \\
\hline MO & -1.2473 & $-4.5933 * * *$ \\
\hline CAB & -1.1747 & $-7.0589 * * *$ \\
\hline
\end{tabular}

Notes:

(i) Critical values at 1\%, 5\% \& 10\% for Schmidt and Phillips test are -3.56, -3.02 \& 2.75 respectively. Source : Schmidt, P. and Phillips, P. C. B. (1992), "LM tests for a unit root in the presence of deterministic trends", Oxford Bulletin of Economics and Statistics, vol. 54, p. 257-287.

(ii) $* * *$ signifies statistically significant at $1 \%$ level

(iii) ** signifies statistically significant at $5 \%$ level

(iv) * signifies statistically significant at $10 \%$ level

Table 5. Engle Granger Test for Pairwise Co-Integration

\begin{tabular}{|lllll|}
\hline Equation $\mathbf{Y}_{\mathbf{t}}$ on $\mathbf{X}_{\mathbf{t}}$ & Trend & Statistic & $\mathbf{p}$-value & $\begin{array}{l}\text { Conclusion(Cointegration } \\
\text { Present })\end{array}$ \\
\hline TCI on REERX & YES & $\begin{array}{l}-1.1668 \\
(\text { Lag-8) }\end{array}$ & 0.9647 & NO \\
\hline REERX on TCI & YES & $\begin{array}{l}-3.9584 \\
(\text { Lag-1) }\end{array}$ & 0.0308 & YES \\
\hline TCI on NEERX & YES & $\begin{array}{l}-2.2363 \\
(\text { Lag-6) }\end{array}$ & 0.6613 & NO \\
\hline NEERX on TCI & YES & $\begin{array}{l}-3.9147 \\
(L a g-3)\end{array}$ & 0.0348 & YES \\
\hline TCI on REERT & YES & $\begin{array}{l}-3.2122 \\
(L a g-0)\end{array}$ & 0.2121 & NO \\
\hline
\end{tabular}




\begin{tabular}{|c|c|c|c|c|}
\hline REERT on TCI & NO & $\begin{array}{l}-3.9983 \\
(\text { Lag-1) }\end{array}$ & 0.0071 & YES \\
\hline TCI on NEERT & YES & $\begin{array}{l}-1.4489 \\
(\text { Lag-6) }\end{array}$ & 0.9299 & NO \\
\hline NEERT on TCI & YES & $\begin{array}{l}-2.2782 \\
(\text { Lag-8) }\end{array}$ & 0.6397 & NO \\
\hline TCI on WPI & YES & $\begin{array}{l}-2.5047 \\
(\text { Lag-6) }\end{array}$ & 0.5173 & $\mathrm{NO}$ \\
\hline WPI on TCI & YES & $\begin{array}{c}-1.6708 \\
(\text { Lag-7) }\end{array}$ & 0.8833 & NO \\
\hline TCI on M0 & YES & $\begin{array}{l}-3.8180 \\
(\text { Lag-6) }\end{array}$ & 0.4531 & NO \\
\hline MO on TCI & YES & $\begin{array}{l}-2.6992 \\
(\text { Lag-1) }\end{array}$ & 0.4116 & NO \\
\hline TCI on FOREX & YES & $\begin{array}{l}-2.5621 \\
(\text { Lag-6) }\end{array}$ & 0.4858 & NO \\
\hline FOREX on TCI & YES & $\begin{array}{c}-2.1288 \\
(\text { Lag-6) }\end{array}$ & 0.7142 & NO \\
\hline REERT on WPI & YES & $\begin{array}{l}-3.7079 \\
(\text { Lag-1) }\end{array}$ & 0.0612 & YES \\
\hline WPI on REERT & YES & $\begin{array}{l}-1.5327 \\
(\text { Lag-8) }\end{array}$ & 0.9147 & NO \\
\hline REERT on M0 & YES & $\begin{array}{l}-3.5710 \\
(\text { Lag-1) }\end{array}$ & 0.0842 & YES \\
\hline MO on REERT & YES & $\begin{array}{c}-0.1010 \\
(\text { Lag-0) }\end{array}$ & 0.999 & NO \\
\hline $\begin{array}{l}\text { REERT on } \\
\text { FOREX }\end{array}$ & YES & $\begin{array}{c}-3.6618 \\
(\text { Lag-1) }\end{array}$ & 0.0676 & YES \\
\hline $\begin{array}{l}\text { FOREX on } \\
\text { REERT }\end{array}$ & YES & $\begin{array}{l}-0.0608 \\
(\text { Lag-0) }\end{array}$ & 0.9424 & NO \\
\hline NEERT on WPI & $\mathrm{NO}$ & $\begin{array}{l}-3.3073 \\
(\text { Lag-3) }\end{array}$ & 0.0537 & YES \\
\hline WPI on NEERT & YES & $\begin{array}{c}-1.5182 \\
(\text { Lag-8) }\end{array}$ & 0.9175 & NO \\
\hline NEERT on M0 & YES & $\begin{array}{l}-3.8045 \\
(\mathrm{Lag}-3)\end{array}$ & 0.0469 & YES \\
\hline Mo on NEERT & YES & $\begin{array}{c}-1.0978 \\
(\text { Lag-3) }\end{array}$ & 0.9703 & NO \\
\hline $\begin{array}{l}\text { NEERT on } \\
\text { FOREX }\end{array}$ & YES & $\begin{array}{l}-3.5267 \\
(\mathrm{Lag}-3)\end{array}$ & 0.0934 & YES \\
\hline $\begin{array}{l}\text { FOREX on } \\
\text { NEERT }\end{array}$ & YES & $\begin{array}{l}-1.0144 \\
(\text { Lag-5) }\end{array}$ & 0.976 & $\mathrm{NO}$ \\
\hline
\end{tabular}




\begin{tabular}{|lclll|}
\hline WPI on MO & YES & $\begin{array}{l}-2.6311 \\
(\text { Lag-8) }\end{array}$ & 0.4482 & NO \\
\hline Mo on WPI & YES & $\begin{array}{l}-1.3032 \\
(\text { Lag-8) }\end{array}$ & 0.9506 & NO \\
\hline WPI on FOREX & YES & $\begin{array}{l}-2.565 \\
(\text { Lag-8) }\end{array}$ & 0.4841 & NO \\
\hline FOREX on WPI & YES & $\begin{array}{l}-0.8809 \\
(\text { Lag-8) }\end{array}$ & 0.9831 & NO \\
\hline MO on FOREX & YES & $\begin{array}{l}-3.6164 \\
(L a g-8)\end{array}$ & 0.0755 & YES \\
\hline FOREX on M0 & NO & $\begin{array}{l}-2.9021 \\
(L a g-8)\end{array}$ & 0.1354 & NO \\
\hline
\end{tabular}

Table.6. Pairwise Granger Causality Test

\begin{tabular}{|c|c|c|c|c|c|}
\hline $\begin{array}{l}\text { Depende } \\
\text { nt } \\
\text { Variable } \\
\text { s }\end{array}$ & $\begin{array}{l}\text { Explanatory } \\
\text { Variables }\end{array}$ & Lags & $\begin{array}{l}\text { F- } \\
\text { Statist } \\
\text { ic }\end{array}$ & p-value & Remarks \\
\hline$\Delta \mathrm{TCI}$ & $\begin{array}{l}\Delta \mathrm{TCI}, \\
\Delta \mathrm{REERX}\end{array}$ & 1 & 3.1677 & 0.0238 & Causality From REERX $\rightarrow$ TCI \\
\hline $\begin{array}{l}\Delta \text { REER } \\
X\end{array}$ & $\begin{array}{l}\triangle \text { REERX, } \\
\Delta \mathrm{TCI}\end{array}$ & 1 & 3.2383 & 0.0209 & Causality From TCI $\rightarrow$ REERX \\
\hline$\Delta \mathrm{TCI}$ & $\begin{array}{l}\Delta \text { TCI, } \\
\Delta \text { NEERX } \\
\end{array}$ & 1 & 0.0981 & 0.7554 & No Causality From NEERX $\rightarrow$ TCI \\
\hline $\begin{array}{l}\Delta \text { NEER } \\
X\end{array}$ & $\begin{array}{l}\triangle \mathrm{NEERX}, \\
\Delta \mathrm{TCI}\end{array}$ & 1 & 0.0404 & 0.8413 & No Causality From TCI $\rightarrow$ NEERX \\
\hline$\Delta \mathrm{TCI}$ & $\begin{array}{l}\Delta \text { TCI, } \\
\Delta \text { REERT }\end{array}$ & 1 & 0.4542 & 0.5033 & No Causality From REERT $\rightarrow$ TCI \\
\hline $\begin{array}{l}\Delta \text { REER } \\
T\end{array}$ & $\begin{array}{l}\mathrm{REERT}, \\
\triangle \mathrm{TCI}\end{array}$ & 1 & 2.1837 & 0.0416 & Causality From TCI $\rightarrow$ REERT \\
\hline$\Delta \mathrm{TCI}$ & $\begin{array}{l}\Delta \text { TCI, } \\
\Delta \text { NEERT }\end{array}$ & 1 & 0.0165 & 0.8981 & No Causality From NEERT $\rightarrow$ TCI \\
\hline $\begin{array}{l}\Delta \text { NEER } \\
\mathrm{T}\end{array}$ & $\begin{array}{l}\mathrm{NEERT}, \\
\triangle \mathrm{TCI}\end{array}$ & 1 & 0.0711 & 0.7908 & No Causality From TCI $\rightarrow$ NEERT \\
\hline$\Delta \mathrm{TCI}$ & $\Delta \mathrm{TCI}, \Delta \mathrm{WPI}$ & 4 & 1.5788 & 0.1972 & No Causality From WPI $\rightarrow$ TCI \\
\hline$\Delta \mathbf{W P I}$ & $\Delta \mathrm{WPI}, \Delta \mathrm{TCI}$ & 4 & 0.5752 & 0.6821 & No Causality From TCI $\rightarrow$ WPI \\
\hline$\Delta \mathrm{TCI}$ & $\Delta \mathrm{TCI}, \Delta \mathrm{M} 0$ & 4 & 4.5652 & 0.0037 & Causality From $\mathrm{M} 0 \rightarrow \mathrm{TCI}$ \\
\hline$\Delta \mathbf{M 0}$ & $\Delta \mathrm{M} 0, \Delta \mathrm{TCI}$ & 4 & 0.9405 & 0.4498 & No Causality From TCI $\rightarrow$ M0 \\
\hline$\Delta \mathrm{TCI}$ & $\begin{array}{l}\Delta \text { TCI, } \\
\Delta \text { FOREX }\end{array}$ & 4 & 3.4956 & 0.0148 & Causality From FOREX $\rightarrow$ TCI \\
\hline $\begin{array}{l}\Delta \mathrm{FORE} \\
\mathrm{X}\end{array}$ & $\begin{array}{l}\Delta \text { FOREX, } \\
\Delta \mathrm{TCI}\end{array}$ & 4 & 5.6405 & 0.0010 & Causality From TCI $\rightarrow$ FOREX \\
\hline $\begin{array}{l}\Delta \text { REER } \\
T\end{array}$ & $\begin{array}{l}\Delta \text { REERT, } \\
\Delta \text { WPI }\end{array}$ & 1 & 0.0990 & 0.7542 & No Causality From WPI $\rightarrow$ REERT \\
\hline$\Delta W P I$ & $\Delta \mathrm{WPI}$ & 1 & 0.0160 & 0.8997 & No Causality From REERT $\rightarrow$ WPI \\
\hline
\end{tabular}




\begin{tabular}{|c|c|c|c|c|c|}
\hline & $\triangle \mathrm{REERT}$ & & & & \\
\hline $\begin{array}{l}\Delta \text { REER } \\
\text { T }\end{array}$ & $\begin{array}{l}\triangle \mathrm{REERT}, \\
\Delta \mathrm{M} 0\end{array}$ & 4 & 1.0488 & 0.3934 & No Causality From M0 $\rightarrow$ REERT \\
\hline$\Delta \mathbf{M 0}$ & $\begin{array}{l}\triangle \mathrm{M} 0, \\
\triangle \mathrm{REERT}\end{array}$ & 4 & 0.4230 & 0.7912 & No Causality From REERT $\rightarrow$ M0 \\
\hline $\begin{array}{l}\Delta \text { REER } \\
T\end{array}$ & $\begin{array}{l}\triangle \text { REERT, } \\
\triangle \text { FOREX }\end{array}$ & 1 & $\begin{array}{l}0.6463 \\
1\end{array}$ & 0.4251 & $\begin{array}{l}\text { No Causality From FOREX } \rightarrow \\
\text { REERT }\end{array}$ \\
\hline $\begin{array}{l}\Delta \text { FORE } \\
X\end{array}$ & $\begin{array}{l}\triangle \mathrm{FOREX}, \Delta \\
\text { REERT }\end{array}$ & 1 & 4.7445 & 0.0339 & Causality From REERT $\rightarrow$ FOREX \\
\hline $\begin{array}{l}\triangle N E E R \\
T\end{array}$ & $\begin{array}{l}\triangle \mathrm{NEERT}, \\
\Delta \mathrm{WPI}\end{array}$ & 4 & $\begin{array}{l}0.5630 \\
6\end{array}$ & 0.6907 & No Causality From WPI $\rightarrow$ NEER \\
\hline$\Delta \mathbf{W P I}$ & $\begin{array}{l}\Delta \text { WPI } \\
\Delta \text { NEERT }\end{array}$ & 4 & 1.6480 & 0.1797 & No Causality From NEERT $\rightarrow$ WPI \\
\hline $\begin{array}{l}\Delta \text { NEER } \\
T\end{array}$ & $\begin{array}{l}\triangle \text { NEERT, } \Delta \\
\text { M0 }\end{array}$ & 4 & 2.6760 & 0.0444 & Causality From $\mathrm{M} 0 \rightarrow \mathrm{NEERT}$ \\
\hline$\Delta \mathbf{M 0}$ & $\begin{array}{l}\triangle \mathrm{M} 0, \\
\triangle \mathrm{NEERT}\end{array}$ & 4 & 1.5353 & 0.2090 & No Causality From NEERT $\rightarrow$ M0 \\
\hline $\begin{array}{l}\Delta \text { NEER } \\
T\end{array}$ & $\begin{array}{l}\triangle \text { NEERT, } \\
\triangle \text { FOREX }\end{array}$ & 1 & 0.3271 & 0.5698 & $\begin{array}{l}\text { No Causality From FOREX } \rightarrow \\
\text { NEERT }\end{array}$ \\
\hline $\begin{array}{l}\Delta \text { FORE } \\
X\end{array}$ & $\begin{array}{l}\triangle \text { FOREX, } \\
\triangle \text { NEERT }\end{array}$ & 1 & 4.1326 & 0.0472 & Causality From NEERT $\rightarrow$ FOREX \\
\hline$\Delta \mathrm{WPI}$ & $\Delta \mathrm{WPI}, \Delta \mathrm{M} 0$ & 5 & 2.3144 & 0.0615 & Causality From $\mathrm{M} 0 \rightarrow$ WPI \\
\hline$\Delta \mathbf{M 0}$ & $\Delta \mathrm{M} 0, \Delta \mathrm{WPI}$ & 5 & 5.3932 & 0.0007 & Causality From WPI $\rightarrow \mathrm{M} 0$ \\
\hline$\Delta \mathbf{W P I}$ & $\begin{array}{l}\Delta \text { WPI, } \\
\triangle \text { FOREX }\end{array}$ & 4 & 1.7871 & 0.1490 & No Causality From FOREX $\rightarrow$ WPI \\
\hline $\begin{array}{l}\Delta \text { FORE } \\
X\end{array}$ & $\begin{array}{l}\triangle \mathrm{FOREX}, \\
\Delta \mathrm{WPI}\end{array}$ & 4 & 2.9880 & 0.0291 & Causality From WPI $\rightarrow$ FOREX \\
\hline$\Delta \mathbf{M O}$ & $\begin{array}{l}\triangle \mathrm{M} 0 \\
\triangle \mathrm{FOREX}\end{array}$ & 5 & 1.2155 & 0.3196 & No Causality From FOREX $\rightarrow$ M0 \\
\hline $\begin{array}{l}\Delta \text { FORE } \\
\mathbf{X}\end{array}$ & $\begin{array}{l}\triangle \mathrm{FOREX} \\
\Delta \mathrm{M} 0\end{array}$ & 5 & 3.5077 & 0.0101 & Causality From $\mathrm{M} 0 \rightarrow$ FOREX \\
\hline
\end{tabular}

\section{Conclusion}

Theoretical literature exploring the consequences of capital inflow is complex and cannot be generalized for all the countries. Different countries have experienced different consequences in response to capital inflow. Hence empirical assessment of possible implication of capital inflows is necessary.

Trend behavior of total capital inflows and its components shows that total capital inflows increases tremendously over the period especially after the year2000-01. Trend behavior of foreign direct investment shows steady upward trend without much fluctuation while foreign institutional investment shows upward trend with fluctuations over the period. 
Trend behavior of real effective exchange rate (both export based and trade based) shows upward trend especially after 1999, while net effective exchange rate (both export based and trade based) shows some negative trend.

Foreign exchange reserve highly upward trend behavior of nominal effective and foreign exchange reserve shows the active interventionist role played by the RBI for maintaining exchange rate fluctuations. Due to the intervention by the RBI domestic currency does not appreciate much over the period though there are some short episodes of appreciation of currency in response to large capital inflows. Money supply increases tremendously over the period but it is difficult to say how much of it is due to the capital inflows.

Divergence between real and nominal exchange rate shows that price level in home country increases in relation to trading partners. Current account balance does not experience any significant deterioration in response to total capital inflows.

Capital account balanced (CAB) is the only variable which is stationary in level form. There are also some evidence that nominal effective exchange rate (both export based \& trade based) is stationary in level form. All other variables are non stationary in level form.

Hence time trend of all variables except current account balance and nominal exchange rate are diverging from equilibrium. Cointegration test confirms the long run equilibrium relation between real effective exchange rate and total capital inflows. Causality test shows the bidirectional causality between REERX \& TCI, between FOREX \& TCI and unidirectional causality from TCI to REERT.

Some of the important findings of our analysis are as follows (a) nominal effective exchange in India does not appreciate in response to capital inflows. (b) there is some linkage between real effective exchange rate and capital inflows. The trend behavior shows that gap between real and nominal effective exchange rate increases which means price level in India increases in relation to trading partners. (c) Foreign exchange reserve increases tremendously due to the intervention by the RBI in foreign exchange market. (d) Current account balance does not deteriorate much as in case of some Latin American countries.

\section{References}

Chakraborty, Indrani. (2001), "Economic Reforms, Capital Inflows and Macro Economic Impact in India", CDS Working Paper, No.311.

Chakraborty, Indrani (2003), "Liberalization of Capital Flows and the Real Exchange Rate in India: A VAR Analysis", CDS Working Paper, No- 351, Sept.

Engle, R.F. and Granger, C.W.J. (1987), "Cointegration and Error- Correction: Representation, Estimation and Testing", Econometrica, 55.

Granger, C.W.J. (1981), "Some Properties of Time-Series Data and Their Use in Econometric Model Specification", Journal of Econometrics, 16.

Granger, C.W.J. and Newbold, P. (1974), "Spurious Regressions in Econometrics", Journal of Econometrics, 2. 
Hanias, P.M., Curtis, G.P. and Thalassinos, E.J. (2007). Non-linear dynamics and chaos: The case of the price indicator at the Athens Stock Exchange. International Research Journal of Finance and Economics, 11(1), 154-163.

Kohli, Renu (2001), "Capital Flows and Their Macro Economic Effects in India", Working Paper ICRIER, No- 64, PP- 11-42.

Kohli, Renu (2003), "Capital Flows and Domestic Financial Sector in India", Economic Political Weekly, Feb. 22. PP-761-68.

Lutkepohl, H. (1991), "Introduction to Multiple Time Series Analysis", Springer-Verlag, New York.

Schmidt, P. and Phillips, P. C. B. (1992). "LM tests for a unit root in the presence of deterministic trends", Oxford Bulletin of Economics and Statistics, vol. 54, p. 257-287.

Thalassinos, I.E., Ugurlu, E. and Muratoglu, Y. (2012a). Income Inequality and Inflation in the EU. European Research Studies Journal, 15(1), 127-140.

Thalassinos, I.E., Hanias P.M. and Curtis G.P. (2012b). Time series prediction with neural networks for the Athens Stock Exchange indicator, European Research Studies Journal, 15(2), 23-31.

Thalassinos, I.E., Hanias, P.M., Curtis, G.P. and Thalassinos, E.J. (2013). Forecasting financial indices: The Baltic Dry Indices. Marine Navigation and Safety of Sea Transportation: STCW, Maritime Education and Training (MET), Human Resources and Crew Manning, Maritime Policy, Logistics and Economic Matters; Code 97318, 283-290, ISBN: 978-113800104-6. 